\title{
Employee Engagement Practices in Banking of Bangladesh: An Analysis and Evaluation of Critical Success Factors
}

\author{
Rabeya Akther Shumi ${ }^{1 *}$ \\ Sharmin Begum ${ }^{2}$ \\ Jatiya Kabi Kazi Nazrul Islam University, Bangladesh ${ }^{1,2}$
}

\begin{abstract}
This paper focuses on the factors that are inextricably related to the employee engagement process. The study has scrutinized the factors, which are more potent on employee engagement regarding the banking sector in Bangladesh. Some components, for instance, performance management system, goals, leadership, have outplayed the other factors and acted as a mediator to the employee performance enhancement. Data was collected from the 120 full-time employees from 14 banks in Mymensingh and around that district by the survey method. The Principal Component Analysis (PCA) and Factor Extraction have been executed to find the successful factors; the study shows that there are some latent factors, and by selecting the significant factors, employee engagement can be enhanced more effectively. On that note, the examination of eight success factors led to make a cluster into three major components. Consequently, the first component has been labelled as a performance management agreement that consists of a performance management system and leadership agreement, the second component as an awareness of goals and objectives which comprises of the plan and, the final component as a leadership role on an understanding job that subsumes leadership roles. In addition to that, data has collected from diverse groups and locations followed by convenient sampling and, sometimes responses were oblique because respondents felt intimidated by supervisor reaction about discriminated leadership style. The results depict that success factors are influencing the employee engagement process and also suggests that management should focus on the elements to get the best outcome of performance management.

Keywords: Employee Engagement, Performance Enhancement, Factor Analysis, Factor Extractions, Success Factor Interpretations
\end{abstract}

*Corresponding author: Rabeya Akther; Email: phoenixshumi@gmail.com DOI: https://doi.org/10.37227/JIBM-2021-07-1093

\section{Introduction}

Performance management systems are a critical tool that organizations use to translate business strategy into business results by influencing "financial performance, productivity, product or service quality, customer satisfaction, and employee job satisfaction" (Aguinis, 2019). However, difficulties arise when improving the performance of employees working in banks by the top management of it. More importantly, nowadays, job satisfaction is decreasing because there is a bleak picture of employees, engagement, and attachment (Casey \& Sieber, 2016). As complexities 
may arise from different phenomena while measuring performance, employee engagement can settle down much chaos and establish the rules of thumb in measuring performance in a balanced manner. Moreover, performance management and employees' engagement in their respective job at banks have become the interdisciplinary discussed issue. Notably, an organization can acquire excellent individual performance if employees are engaged with their work. In a competitive world, employee engagement is crucial for banks to attain sustainability (Mozammel \& Haan, 2016). To solve this problem of how the banking sector in Bangladesh should accelerate and manage performance, a systematic attempt to involve bank employees has been made regarding this issue. In this context, the appropriate research topic is " Employee Engagement Practices in Banking of Bangladesh: An Analysis and Evaluation of Critical Success Factors", which can answer the many untapped questions. Here the broad objective of this study is to assess how employee engagement practices enhance the performance of employees in the banking sector of Bangladesh. Besides analyzing the general objectives, scrutinizing the existing nature of employee engagement practices in the banking sector; identifying the factors that influence performance through the employee engagement process; evaluating the preferences of the success factors of employees in the engagement process and, making suggestions for the betterment on the employee engagement process are specific objectives of the study.

\section{Background of the study}

The financial sector of Bangladesh is attributed to be small and as well as underdeveloped, though the banking industry in Bangladesh is the most prominent service sector, which is contributing a significant proportion to the GDP of Bangladesh is still underdeveloped compared to the international standard (Mozammel \& Haan, 2016). Millions of skilled professionals are working under the same umbrella for the economic and national development of the country (Ahmed \& Rahman, 2020). Sixty-one banks (Financial System, Banks and FIs, 2021), including state-owned, commercial, foreign, and specialized banks, are actively operating in Bangladesh. In the banking industry, the Job-demand and job pressure are exceptionally high, that every employee has to perform accordingly and engage wholeheartedly. Essentially when job demands, the bad things are chronically high and are not compensated by job resources the good things, employee's energy is progressively drained (Schaufeli, 2017). The absence of job engagement can lead to severe damage to professional and personal career and goals. So to say, employee engagement is not an alternative way of making it happens; it has become the most demanding actors for accomplishing a job now a day.

Performance management which, is a critical aspect of organizational effectiveness and the critical process through which work is accomplished. It is considered a top priority of managers how to use human capital at its peak (Gruman \& Saks, 2010). Performance management focuses on the task along with contextual performances that are formally part of job emphasis on organizational citizenship behaviour, ultimately contribute to the success of the job (Bozionelos \& Singh, 2017). To foster these specific tasks, an individual must have to engage in the position to attain personal and organizational goals. Employee engagement manifests the psychological presence while attending a job or task (Kahn, 1990). When people are psychologically present, they feel and are attentive, connected, integrated, and focused in their role performances (Kahn, 1992). (Rothbart, 2001) defined employee engagement as the psychological presence of the employees of the organization that involves two components, attention and absorption; attention refers to the cognitive availability the amount of the time spent thinking of the role, and absorption means being engulfed in the position (Agrawal, 2015).

\section{Theoretical and Conceptual Framework}

There are available theories and models on performance management and the employee engagement process despite; this study is based on common organizational practice. Specifically, the banking industry has not yet been studied the engagement practices of employees for improving their performance, so there is no developed theory or relevant model to follow. But the following 'Engagement Management Model' has been observed with the literature reviewed earlier for the nourishment of this study. 


\section{Theoretical Framework}

As the main thrust of this study is to identify how employee engagement enhances organizational performance management in the banking sector of Bangladesh, this segment illustrated the conceptual framework of the study where "Performance management" is the dependent variable and "Employee Engagement" is the independent variable.

Aguinis stated that performance management is an ongoing process of identifying, measuring, and developing the performance of individuals and teams and aligning performance with the strategic goals of the organization (Aguinis, 2019).

According to Kahn (1990), employee engagement is harnessing members of the organization to their work role, and when they are engaged, they verbalize physical, emotional, cognitive behaviour in-role performance (Saks \& Gruman, 2014). This study depicted the Gruman and Saks (2011:128) proposed engagement management model (figure: 1) for deploying how employee engagement works as a tool for improving performance management within the banks of Bangladesh. Since Gruman and Saks (2011) mentioned that the model depicts a sequence of steps, it is essential to note that the process is ongoing, continuous, and shown in the figure, performance agreement and engagement facilitation feed into employee engagement.

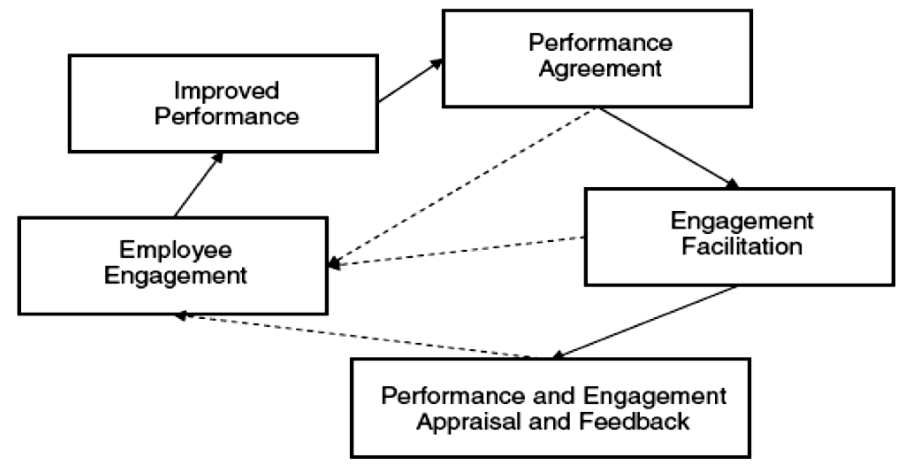

Figure 1: The Employee Engagement Management Model (Arrows around the circumference of the model represent the engagement management process). Dotted lines represent the drivers of employee engagement.

Source: Gruman and Saks (2011:128)

\section{Conceptual Framework of the Study}

According to the cause and effect relationship, the conceptual framework shows the interrelationship between dependent and independent variables. So, the conceptual framework of this research has been illustrated below (figure: 2) where the independent variable is 'Employee Engagement', which consists of the variables goal setting, psychological contract, job design, leadership, coaching-mentoring-social support, training, justice, trust and feedback; and the dependent variable is 'Performance Management. These variables have been constructed to analyze and evaluate the present scenario of employee engagement and its effect on performance management in the banking field of Bangladesh described below.

\section{Goal Setting}

A clear, focused, well-explained, and well-communicated goal-setting brings positive employee effectiveness and organizational effectiveness. Setting right goals provide direction to employees, maximize the potential capabilities, by which employee achieve the specific target and accommodate themselves in the room for creativity. When the goal is congruent; employee feels that their goals and values are a good fit, and they are committed to organization's goals and values (Choon \& Low, 2016). Thus, understanding the goal leads an employee to be engaged in the workplace consciously. Additionally, employees always prefer the goal-directed choice where each action is the core of motivation. When a goal is going to be acquired by the employees, generally, they set another higher goal because of their self-efficacy (Locke \& Latham, 2019). This is how aligned goal setting yields the increased engagement in the workplace. 
Another way it can be said that goal setting is a lever that helps foster employee engagement in several ways; making employees' jobs more challenging, proving greater meaning to work, energizing employees to perform better (Mone \& London, 2010). Goal setting leads to positive employee engagement that ultimately leads to positive outcomes and enhances employee performance (Shoaib \& Kohli, 2017). According to Barney and Griffin, organizational goals serve four canonical functions; they provide guidance and direction, facilitate planning, motivate and inspire employees, and help organizations evaluate and control performance (Barney \& Griffin, 1992). Numerous studies have discussed fruitful goal setting's positive impact on employee outcomes within an organization (Medlin \& Green Jr, 2009).

\section{Psychological contract}

The Psychological contract is an implicit accord between employee and organization. The organization is well prepared about the process and conveying that to the employees while employees are mentally available to perform a task and resulting in controlling productivity at an organizational and personal level (Newaz et al., 2021). The psychological contract subsumes an impact on job satisfaction, organizational commitment, intention to quit, and organizational citizenship behaviour, as employee engagement does (Aggarwal, Datta, \& Bhargava, 2007). During the study, we have examined the psychological contract and noticed the psychological states of people that determined the internal work motivation by influencing itself. According to (Arzoumanian, 2018), a study has found that there is a strong correlation among bank employees (Sandhya \& Sulphey, 2021). From the survey conducted on banks (Ishtiaq \& Zeb, 2020), it has been found that there is a strong correlation between the psychological contract and the bank employees. When a Psychological contract has reciprocity, it minimizes the job stress and keeps the employees attached to the work.

Argyris (1960) believed that employees would perform at an optimal level if the organization did not interfere too much with the employee group's norms, and in return, employees would respect the right of the organization to evolve (Argyris, 1960).

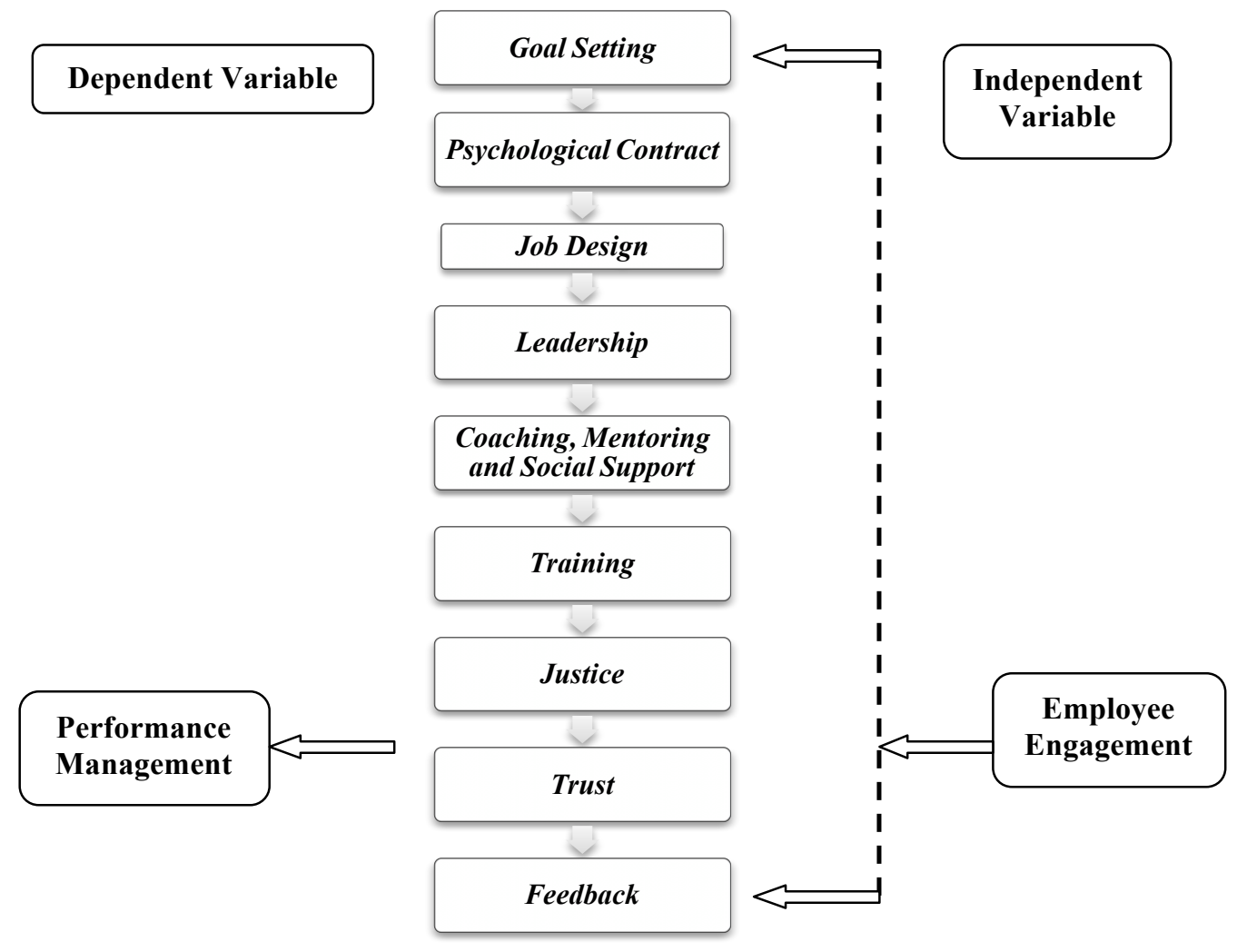

Figure 2: Conceptual framework of the study; (Created by authors) 


\section{Job Design}

The job design relates to employee engagement that is the combination of vigour, dedication, and absorption that are multidimensional motivational contrast (Shantz, Alfes, Truss, \& Soane, 2013). Job design has been identified as a crucial factor for the work engagement of employees; it has been even found as the most critical factor for employee innovativeness. Proper job design that emphasis on employee autonomy and sufficient amount of control, less time pressure increases the employee engagement and innovative work behaviour of employee at an individual level rather than organizational level (Spiegelaere, Gyes, Witte, \& Hootegem, 2015). Practical job design with job autonomy and job feedback proliferate employee engagement; moreover, well design jobs enhance employee commitment, lead to improved individual and group performance outcomes (Kariuki, 2015). Various studies also have proved the strong relationship between job design and engagement, job crafting and engagement moreover, positive associations were found between role clarity, job quality, job control, job enlargement, enrichment, and active coping while sound job design is found (Bailey et al., 2017).

There are several ways of identifying the requirements of a job, such as -Job Rotation (wherein employees of an organization are exposed to several different roles \& profiles across the organization), Job Simplification (which involves identifying mechanical processes, repetitive work, one-product development, tools \& skills required), Job Enlargement (offers more tasks to be performed to the employee) and job Enrichment (Job enrichment method of job design looks at enriching the work of the employee by adding more responsibility, value and decision-making powers). These job requirements improve an individual not only professionally but also add value to personal development (Business-concept, 2019).

\section{Mentoring and Coaching}

The mentoring and coaching have one clear purpose for the organization and its people wherein they work through the learning and development of an individual, additionally that learning and development experience involves employees applying their skills at work confidently and ensures work engagement. Nevertheless, mentoring has a different meaning from coaching; mentors are a highly skilled and experienced person in the arena who gives the guidelines to the mentee on formulating career and network (Jones et al., 2016). Whereas in coaching, a coach shares the same skill set with the coachee and, the coachee ruminate the actual potentiality of work (Hakro \& Mathew, 2020). When mentoring and coaching act as reflective learning opportunities for change, it is possible to be clear about the terms we use to describe the difference. Briefly, the name of the activity is less crucial than its purpose and what is happening, as it will influence the type of learning outcome (Brockbank \& Mcgill,2012). DeCenzo and Robbins define, when a senior employee takes role proactively to guide another person, we refer to this task as mentoring or coaching (DeCenzo \& Robbins, 2013-14). The terms mentoring and coaching often get used interchangeably. The mentor becomes a source of wisdom, teaching, and support, but not someone who observes and advises on specific actions or behavioural changes in daily work (The Balance Career, 2019).

Social support defines the support and assistance that each person attains from his fellow beings. In a society, help can come from any source, such as from close relatives like family members, neighbours, and even from colleagues (Communication Theory, 2019).

\section{Leadership}

Leadership is the elementary operator for employee engagement. When leaders have technical skills above the rim and when an employee has enough confidence in the leader, employee engagement acts smoothly for employees and leaders (Radda, Majidadi, \& Akanno, 2015). Especially, transactional leadership has a strong correlation with the employee engagement process where leaders dominate an essential role in creating a favourable environment where an employee can be engaged wholeheartedly, particularly in nascent stages of the carrier of young employees (Popli \& Rizvi, 2016). Employee engagement has considered as the by-product of leadership, in that processing employee has candid bonding with an incumbent that ensures empowerment, involvement, and development (Osborne \& Hammoud, 2017). According to a study conducted on different cultures, it has found that different leadership styles have a different impact on employee 
engagement. The study showed different types of leadership such as transformational, authentic, ethical, servant, abusive supervision, transactional, empowering, charismatic and, engaging. Among these, all leadership fashions are somehow positively correlated to employee engagement except abusive supervision irrespective of different cultural dimensions ( $\mathrm{Li}$ et al., 2021). Leadership and followership are a natural flow and embedded relation in the social fabric. Leaders who focus on-task behaviour and inspire to promote task behaviour are prosperous in employee engagement (Schaufeli \& Salanova, 2008). Leaders or organizational managers play a vital role in implementing the employee engagement process by implementing strategic planning, developing engagement-related skills, motivating employees through improving skills and confidence with a continuous monitoring program. Leaders assist employees in exploring the best version of personal presence (physical, cognitive, and emotional) of employees at work that is titled as "preferred self" responsive for task behaviour (Kahn, 1992).

\section{Training}

Training along with employee engagement are consequential forecasters of employee performance; as a result, training acts as a metamorphosis in employee's current state to developing stages; training enhances performance on the job and off the job training (Sendawula et al., 2018). Training plays uncountable roles in the banking sector of Bangladesh, from skill development to employee performance; moreover, it is recommendable that training should be included as a core part of the organizational policy (Ibrahim, Rodzi, \& Zin, 2021). Gary Dessler defined training as the process of teaching new employees the basic skills they need to perform their jobs. Decenzo \& Robbins explained programs that are more present-day oriented, focuses on an individual's current jobs, enhancing specific skills and abilities to perform their job called training immediately. Ricky W. Griffin defined training usually refers to teaching operational or technical employees how to do the job for which they were hired (HRM Practice, 2018).

\section{Justice}

Organizational justice has a deep-rooted connection with the employee engagement process and can moderate the perception likewise actions and responses of employees (O'Connor \& Henry, 2019). In the performance appraisal context, four forms of justice perceptions can be delved, namely procedural, distributive, interpersonal, and informational. Therefore, perceptions of justice in performance appraisal can drive employees' satisfaction and their engagement with psychological safety, sense of self-worth, group standing (Gupta, 2013). However, a study conducted by Byrne et al. (Byrne, Peter, \& Weston, 2016) found that distributive justice is highly relatable to employee engagement whereas, procedural justice is only working when the perception of trust in higher management is at the apex (Saks, 2019).

\section{Trust}

Employee engagement is positively related to organizational trust. Trust is a reciprocal force that plays a vital role in building interpersonal relationships and influences engagement to work and organization (Stangrecka \& Iddagoda, 2020). That trust is a sense of confidence created on the notion of meaningful engagement (Jena, Pradhan, \& Panigrahy, 2018), which is a significant issue particularly for competitive industries such as banks wherein, constructing trust in employees and empowering them can yield conspicuous results for banks, however eroding that issue in managers can toll negative image toward the bank (Zameer et al., 2018).

Moreover, trust is professed as a substitute for hierarchical control in organizations. Initiating, increasing, and maintaining trust is particularly important to managerial effectiveness and organizational performance since trust generates voluntary cooperation, which is essential since working environments have transformed immensely over the years (Atkinson and Butcher, 2003). The engagement of employees cannot exist without trust since trust and fairness are the basements for employees to feel and act engage (Macey, Schneider, Barbera, and Young, 2009). 


\section{Feedback}

The performance feedback process is continuous between managers and employees. Feedback demonstrates that one has to meet expected expectations in most contemporary work roles (Keating \& Heslin, 2015). The exchange of information involves both performances expected and performance exhibited and, constructive feedback can praise good performance or correct poor performance that should always be tied to the performance standards (Shumi \& Begum, 2017). Engagement of employees is acknowledged as one of the crucial factors leading to the success of organizations in sustaining competitive advantage (Nair \& Salleh, 2015). Managers need to be conscious of the effects of their feedback and follow up on the situation to see what changes have been made by the employees. Positive feedback promotes engagement by affecting the socioemotional climate in organizations (Schaufeli and Salanova, 2007). Positive feedback driven by proper leadership can enhance employee engagement at work, reduce job pressure and burnout; moreover, the environment of employee safety increases (Sexton et al., 2018).

\section{Research Methodology}

The method of the study is exploratory with quantitative analysis. The sample size of one hundred twenty (120) has been drawn as a convenience sampling method that represents the part of the population for this study. Survey design is suitable for this study in obtaining the information for explaining social phenomena where the population is too large to observe directly and the best option for collecting primary data. The study intended to evaluate the influence of employee engagement on improving the performance of bank employees in Bangladesh. This study has been conducted among the employees of 14 banks (state-owned commercial, conventional private commercial, specialized, Islami Shariah based private commercial banks) of the Mymensingh division, which are located in various districts such as Mymensingh, Jamalpur, Netrokona, and Sherpur. The data has been garnered from both primary and secondary sources; interviewing the bankers from 14 banks for aiding survey method is considered as primary sources and collecting resources from published books, e-books, journals, articles, newspapers, relevant documents and publications of government agencies, reports of different organizations, internet sources which have considered as a secondary source for the study. This study has been done by collecting data through semi-structured questionnaires.

The Five-Point Likert Scale has been used where a question being asked in a five-point 'Likert Scale' that ranges from (1 to 5) 'Strongly Disagree' to 'Strongly Agree'. Data has been analyzed and processed by the Statistical Package for Social Science (SPSS) software. For the quantitative analysis of data, univariate, bivariate, and multivariate analyses have been performed. The internal consistency of the scale has been calculated by Cronbach's Alpha (Coakes \& Ong, 2011). According to Kim and Mueller (1978), Factor analysis is based on the fundamental assumption that some underlying factors that are smaller in number than the number of observed variables are responsible for the co-variation among the observed variables (Kim \& Mueller, 1978). Factor Analysis is the procedure that has always been used by researchers to organize, identify and minimize big items from the questionnaire to certain constructs under one dependent variable in research. Kaiser-Meyer-Olkin and Bartlett's test (KMO test) was done to identify whether the data is suitable for factor analysis.

\section{Data Analysis and Findings}

In this research, data has been presented and analyzed by using univariate and bivariate analysis. From the distribution based on the survey questionnaire, the first age group of the respondent was $61.7 \%$, followed by the age group 26 to 35 years. The second-largest age group is 36 to 45 years that is $31.7 \%$ among the respondents. Among the total 120 respondents, the number of male participants is 102 that is $85 \%$, and the female participants are $15 \%$. The study area of this research was in different branches of banks of Mymensingh, Jamalpur, Sherpur, and Netrokona districts where most of the respondents have completed their post-graduation, few of them have completed diploma courses on bank management. From the field survey, it has been found that $97.5 \%$ of the respondent has post-graduation degree and only $2.5 \%$ of them have not completed their postgraduation. Among the total respondents, $67.5 \%$ are working at entry-level, $30 \%$ of them are mid- 
level employees and, the rest $2.5 \%$ of them are at an executive level. Hence, from the field survey, it has been found that most of the respondents who participated in this study are entry-level employees. Among the 120 respondents, only 3 of them are working at an executive level. The main reason behind the lower percentage of executive employees is that they possess the desire to work in the capital city rather than the Mymensingh division. It has been identified that most of the employees $52.5 \%$ have 0 to 5 years of experience in the banking sector. $39.2 \%$ have $6-10$ years of experience, and only $1.7 \%$ have experienced more than 16 years.

Table 1: Data Summary of Field Survey

\begin{tabular}{|c|c|c|c|c|c|c|c|c|c|}
\hline Gender & Number & Age & Frequency & $\begin{array}{c}\text { Education } \\
\text { Level }\end{array}$ & Frequency & Designation & Frequency & Experience & Frequency \\
\hline Male & 102 & $26-35$ & 74 & Graduate & 3 & Entry Level & 81 & $0-5$ & 63 \\
\hline Female & 18 & $36-45$ & 38 & $\begin{array}{c}\text { Post- } \\
\text { graduate }\end{array}$ & 117 & Mid-Level & 36 & $06-10$ & 47 \\
\hline & & $46-55$ & 8 & & & Executive & 3 & $11-15$ & 8 \\
\hline & & & & & & & & 16 -above & 2 \\
\hline Total & 120 & & 120 & & 120 & & 120 & & 120 \\
\hline
\end{tabular}

Source: Field survey, Mymensingh, Nov2020-Jan 2021

Validity and Reliability Test

Validity denotes the proven relationship of a selection device to relevant criteria. Criterion-related validity is the degree to which a particular selection device accurately predicts the level of performance or essential elements of work behaviour (Decenzo \& Robbins, 2010, pp. 171-172). Measuring the validity of this research instrument with fewer modifications has been adopted from Gruman, and Saks's (2011:128) proposed engagement management model. To calculate the employee performance with selective variables which are chosen from the model are pretty accurate and appropriate because the model has already been tested.

According to Hair et al. (2006), reliability is the degree to which the observed variable measures the actual value. The more reliable measure will show greater consistency than a less reliable measure when the standard is used repeatedly. The rule of thumb for a reasonable reliability estimate is 0.7 or higher. A reliability estimate of between 0.6 and 0.7 may be acceptable if other indicators of model construct validity are good.

Table 2: Reliability test Reliability Statistics

\begin{tabular}{r|r|r|r}
\hline Cronbach's Alpha & Cronbach's Alpha Based on Standardized Items & N of Items \\
\hline .920 & .923 & 17
\end{tabular}

From the above table (table 2), it has been found that Cronbach's alpha is 0.920 , which indicates a significant level of internal consistency for our scale with this specific sample.

\section{Quantitative Analysis}

\section{Factor extraction}

There are various factor extraction methods, namely the Principal Component Analysis method (PCA), Unweighted Least Squares, Generalized Least Squares, and Maximum Likelihood method. Total 16 questions were generated since goall (removal of question 1) would lead to a tiny improvement in Cronbach's alpha, and we found that the "Corrected item-total Correlation" value was low (0.375) for this item. This situation might lead us to consider removing that item.

A total of 16 questions were generated to explore the influence of employee engagement on the performance management among bank employees of the study area. For each success factor, a question being asked in a five-point 'Likert Scale' that ranges from (1 to 5) 'Strongly disagree' to 'Strongly agree'. The applicability of PCA is assessed before the analysis. 


\section{KMO and Bartlett's Test}

The Kaiser-Meyer-Olkin (KMO) is a measure of sampling adequacy that ranges from '0 to 1'. According to Williams, Onsman, and Brown, KMO with more than 0.50 should be sufficient for factor analysis (Williams \& Brown, 2010). In this study, the KMO using the PCA resulted in 0.898 (table 3). Kaiser (1974) suggests if the KMO is in the 0.80s, then the factoring of the variables is meritorious (Kaiser, 1974 cited in Aldahmash, A.; Gravell, A. and Howard, Y. 2017).

Table 3: KMO and Bartlett's test KMO and Bartlett's Test

\begin{tabular}{l|l|r}
\hline Kaiser-Meyer-Olkin Measure of Sampling Adequacy. & .898 \\
\hline Bartlett's Test of Sphericity & Approx. Chi-Square & 974.577 \\
\cline { 2 - 3 } & Df & 120 \\
\cline { 2 - 3 } & Sig. & .000
\end{tabular}

Bartlett's Test of Sphericity Sig. should be less than 0.05 to be considered statistically significant the value is 0.000 here.

\section{PCA analysis, Eigenvalue/Scree plot}

The PCA disclosed many components of which the first three factors had explained the cumulative variance $46.264 \%, 54.428 \%$, and $61.764 \%$ of the total variance respectively (table 4 ). The three factors or components combined presented $61.76 \%$ of the total variance. The first three components are more significant than 1 according to the Eigenvalue and Scree plot; as a result, these components are accepted for further investigation.

Table 4: Principal Component Analysis (Total Variance explained)

Total Eigenvalues and Total Variance Explained

\begin{tabular}{|c|c|c|c|c|c|c|c|c|c|}
\hline \multirow[b]{2}{*}{ Component } & \multicolumn{3}{|c|}{ Initial Eigenvalues } & \multicolumn{3}{|c|}{$\begin{array}{l}\text { Extraction Sums of Squared } \\
\text { Loadings }\end{array}$} & \multicolumn{3}{|c|}{$\begin{array}{l}\text { Rotation Sums of Squared } \\
\text { Loadings }\end{array}$} \\
\hline & Total & $\begin{array}{c}\% \text { of } \\
\text { Variance }\end{array}$ & \begin{tabular}{|c|} 
Cumulative \\
$\%$
\end{tabular} & Total & $\begin{array}{c}\% \text { of } \\
\text { Variance }\end{array}$ & $\begin{array}{c}\text { Cumulative } \\
\%\end{array}$ & Total & $\begin{array}{c}\% \text { of } \\
\text { Variance }\end{array}$ & $\begin{array}{c}\text { Cumulative } \\
\%\end{array}$ \\
\hline 1 & 7.402 & 46.264 & 46.264 & 7.402 & 46.264 & 46.264 & 4.739 & 29.616 & 29.616 \\
\hline 2 & 1.306 & 8.164 & 54.428 & 1.306 & 8.164 & 54.428 & 2.788 & 17.426 & 47.042 \\
\hline 3 & 1.174 & 7.336 & 61.764 & 1.174 & 7.336 & 61.764 & 2.355 & 14.722 & 61.764 \\
\hline 4 & .846 & 5.285 & 67.049 & & & & & & \\
\hline 5 & .724 & 4.528 & 71.577 & & & & & & \\
\hline 6 & .680 & 4.252 & 75.829 & & & & & & \\
\hline 7 & .630 & 3.938 & 79.767 & & & & & & \\
\hline 8 & .575 & 3.596 & 83.363 & & & & & & \\
\hline 9 & .501 & 3.132 & 86.495 & & & & & & \\
\hline 10 & .419 & 2.617 & 89.111 & & & & & & \\
\hline 11 & .396 & 2.475 & 91.587 & & & & & & \\
\hline 12 & .350 & 2.188 & 93.775 & & & & & & \\
\hline 13 & .321 & 2.004 & 95.778 & & & & & & \\
\hline 14 & .255 & 1.593 & 97.372 & & & & & & \\
\hline 15 & .237 & 1.479 & 98.851 & & & & & & \\
\hline 16 & .184 & 1.149 & 100.000 & & & & & & \\
\hline
\end{tabular}

Extraction Method: Principal Component Analysis. 


\section{Factor extraction}

After extracting the number of factors, the data rotation technique has been used for the purpose. The factor rotation target is to simplify the data structure for a better interpretation of the variables. In this study, the Varimax rotation technique has been selected and applied on the three extracted components because the Varimax approach is handy, removes elements more clearly, and is easy to interpret (Field, 2009). Determining the factor loading cut-off and the practical significance level has been studied and investigated. Field (2009) suggests that regardless of sample size, a factor should be considered reliable if it has four or more loadings with 0.6 or more. On the other hand, (Stevens, 2012 cited in Aldahmash, A.; Gravell, A. and Howard, Y. 2017) advocates using a factor loading cut-off of 0.4 .

Table 5: The Rotated variable Loadings after Applying the Cut-Off (Factor Loadings $<\mathbf{0 . 5 0}$ Are Excluded)

\begin{tabular}{|c|c|c|c|}
\hline \multicolumn{4}{|c|}{ Rotated Component Matrix } \\
\hline \multirow[t]{2}{*}{ Variable Loading } & \multicolumn{3}{|c|}{ Component } \\
\hline & Component 1 & Component 2 & Component 3 \\
\hline PmA. & .748 & & \\
\hline $1 \mathrm{~d} 2$ & .702 & & \\
\hline Coach & .656 & & \\
\hline goal1 & & .884 & \\
\hline train1 & & .610 & \\
\hline psyc1 & & .602 & \\
\hline ld1 & & & .873 \\
\hline$\overline{\mathrm{jd} 1}$ & & & .755 \\
\hline \multicolumn{4}{|c|}{$\begin{array}{l}\text { Extraction Method: Principal Component Analysis. } \\
\text { Rotation Method: Varimax with Kaiser Normalization. }\end{array}$} \\
\hline
\end{tabular}

Here, the variables that meet the requirements of factor loading cut-off have been extracted from a rotated component matrix (Table 5). The table refers to those values which contain values greater than 0.05. After performing Varimax Rotation Method, Component 1 is ranging the values from 0.656 to 0.748 . As well as, Component 2 is also having values between 0.602 to 0.884 . Later on, Component 3 consists of the values respectively 0.873 and 0.755 .

\section{Factor Interpretation}

According to the conceptual framework, nine key independent variables from that extension total of sixteen variables have been found. After cutting off variables that are below .50 through the rotated variable matrix, the selected eight variables (Table 5) are the critical factors for the employee engagement process that are categorized into three different components. Those factors have been considered as influential which are loaded with more than .70 points.

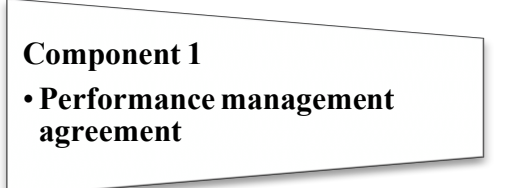

\section{Component 2}

- Awareness of goals and objectives

\section{Component 3}

- Leadership role on understanding job

Figure 3: Labelling of new components

\section{Component 1 (Performance Management Agreement)}

The highest loading in component 1 is a performance management system, and leadership 2 (direction of leaders), respectively .748 and .702 that is known as the performance agreement 
aspect. It is worth mentioning that the proper leadership from a leader encourages employees to perform better and be more engaged in their work.

\section{Component 2 (Awareness of goals and objectives)}

In component 2, goal 1 (the awareness of the department/ organizational goal) scores highest .882 that interprets if employees are aware of the work goal that would be more meaningful to them in achieving objectives.

\section{Component 3 (Leadership role on the understanding job)}

Leadership 1 (leadership role) scores .873 that is the highest value in component 3. Jd1 (clear definition of task and job) scores .755 that contains a good impact on the engagement process. The leader plays a vital role in deciding on employees' engagement process in their work, besides that, what factors determine their engagement and performance process.

On the contrary, the components with low loading train 1 , psyc1, coach score $.610, .602$, and .656 show that training and development program might be less significant than other prioritizing factors as the employees work in local branches where task demand are low relative to the central or competitive braches. In addition to that, coaching, mentoring, social supports are not as salient as more scored factors in different components in the banking sector in the Mymensingh district.

\section{Discussion}

Employee engagement is a very novel concept in Bangladesh and more studies needed to be done yet. From the survey conducted on Mymensingh division, it has found that the respondents who have been serving in different banks in various positions were asked to rate the potent factors (goal setting, psychological attachment, job design, mentoring-coaching-social support, leadership, training, justice, performance feedback). From the findings of the study, it has been observed, performance agreement with the adept leadership engagement can be enhanced in the banking sector in Bangladesh. From the previous study, it has been found that leadership significantly, transformational leadership can strengthen employee engagement and solve particular conundrums in the branch-banking sector in Bangladesh (Mozammel \& Haan, 2016). Awareness of goals and objectives enhances the engagement of the employees. A meaningful job drives an employee toward the attainment of personal and organizational goals, and goal consciousness takes an employee toward better performance and job satisfaction (Nabi et al., 2017). Finally, leaders cooperate to overhaul self-actualization in employees and give them a clear message about their tasks and job in the banking sector. The direction of the leader in achieving the goals acts as a catalyst to employee engagement in banks in Bangladesh.

\section{Research Limitation and Future Direction}

Employee engagement is totally in the nascent stage in the banking industry of Bangladesh and most of the employees are unconscious of the contemporary issue. When the study was conducted in the Mymensingh division, employees encounter the employee engagement concept as unknown, somewhat new in their field of employee performance. It was slightly tricky while retrieving the interview with them because a lack of the knowledge of employees made the interview process lengthy and time-consuming. Moreover, in many cases, employees gave tangent and oblique answers since they were afraid of the supervisor's reaction if their responses were disclosed and privacy broke anyways. In addition to that, since the covid-19 outbreak, we were not able to reach many employees physically or virtually; however, after interviewing each individual who was working in the bank, we delved into many insightful directions of employee engagement that can enhance employee performance in banks.

The future work of this study will involve a more in-depth survey with more responses covering the other divisions and different banks in large cities such as Dhaka in Bangladesh, which will give the factor analysis more validity. Future work also may focus on how prime factors cooperate with 
employee engagement practices and the relation between the component and employee performance to what extent, especially for the banking sector in Bangladesh.

\section{Concluding Remarks and Proposed Model}

Bangladesh's economic expansion has been quite telling from the perspective of the GDP growth rate. Banks and financial institutions are playing a significant role in this growth. Researchers' have been tried to find out the most influential factors that enhance the performance of bank employees of Bangladesh from the employee engagement viewpoint throughout the study.

The prime objective and specific objectives have been attained through the analysis and discussion. This study has constructed a new model from the factor analysis that depicts the three components or factors. These features are performance management agreement, awareness of goals and objectives, and leadership role in understanding job/task that can bring positive change in the performance of employees involved in the banking sector of Bangladesh.

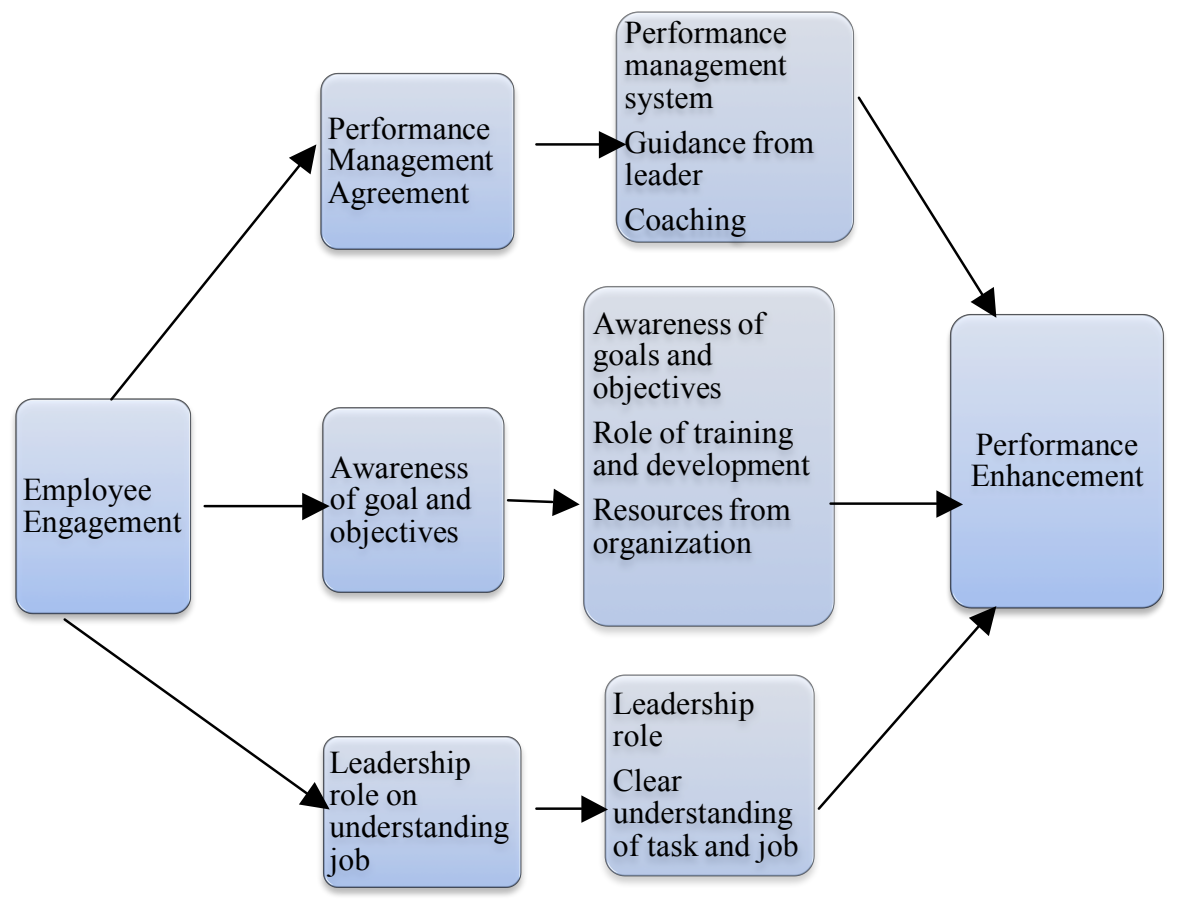

\section{Figure 4: Employee Engagement Model for Performance Enhancement (created by authors)}

This proposed model has been illustrated by the above figure (Figure 4). If this model inaugurated in the banking sector in Bangladesh, it could redress the perception of the back-dated performance management system, working environment, make the employees more confident, improve the superior-subordinate relationship, which will yield with overall performance improvement.

\section{Reference}

Aggarwal, U., Datta, S., \& Bhargava, S. (2007, September). The Relationship between Human Resource Practices, Psychological Contract, and Employee Engagement- Implication for Managing Talent. IIMB Management Review, p. 31.

Agrawal, S. (2015, April 13). Predictors of employee engagement: a public sector unit experience. Strategic HR Review, 14(1/2), p. 95.

Aguinis, H. (2019). Performance Management for dummies. New Jersey: John Wiley \& Sons, Inc.

Ahmed, O., \& Rahman, B. (2020, February ). Employees of Commercial Banks Learning to Unlearn: A case study on the impact of Electronic Banking in the Commercial Banks of Bangladesh. International Journal of Business and technopreneurship, 10(1), 31-50.

Argyris, C. (1960). Understanding Organizational Behavior. Homewood: IL: Dorsey Press. 
Arzoumanian, C. M. (2018). Psychological contracts and their effects on employee engagement. The American University of Beirut. Beirut: Unpublished thesis.

Atkinson, S., \& Butcher, D. (2003, June 1). Trust in Managerial Relationships. Journal of Managerial Psychology, 18(4), 282-304.

Bailey et al., C. (2017). The Meaning of antecedent and outcomes of employee engagement: A narrative synthesis. International Journal of Management Reviews, 31-53.

Banks, C., \& May, K. E. (1999). Performance Management: the real glue in organizations. In A. Kraut, \& K. K. A., Evolving Practices in human resource management (pp. 118-154). San Francisco, USA: CA:Jossey-Bass.

Barney, J. B., \& Griffin, R. W. (1992). The Management of Organizations: Strategy, Structure, Behavior. In J. B. Barney, \& R. W. Griffin, The Management of Organizations. Boston: Houghton Mifflin Company.

Bozionelos, N., \& Singh, S. K. (2017). The relationship of emotional intelligence with task and contextual performance: More than it meets the linear eye. Personality and Individual Differences, 206-211.

Brockbank, A., \& Mcgill, I. (2012). Facilitating Reflective Learning: Coaching, Mentoring, Supervision. In A. Brockbank, \& I. Mcgill, Facilitating Reflective Learning: Coaching, Mentoring, Supervision (pp. 104-108). United States: Kogan Page.

Business-concept. (2019). Retrieved from www.mbaskool.com

Byrne, Z. S., Peter, J. M., \& Weston, J. W. (2016). The struggle with employee engagement: measures and construct clarification using five samples. Journal of Applied Psychology, 101(9), 1201-1227.

Casey, D., \& Sieber, S. (2016). Employees, sustainability and motivation: Increasing employee engagement by addressing sustainability and corporate social responsibility. Research in Hospitality Management, 69-70.

Choon, D. T., \& Low, P. K. (2016). The Impact of Goal Setting on Employee Effectiveness to Improve Organisation Effectiveness: Empirical study of a High-Tech company in Singapore. Journal of Business and Economic Policy, 3(1), 1-16.

Coakes, J. C., \& Ong, C. (2011). SPSS Version 18.0 for Windows Analysis without Anguish (1st ed.). Dougall Street, Australia: John Willy \& Sons Australia Limited.

Communication Theory. (2019). Retrieved from www.communicationtheory.org

DeCenzo, D. A., \& Robbins. (2013-14). Fundamentals of Human Resource Management. UK: JOHN WILEY AND SONS INC.

Decenzo, D. A., \& Robbins, S. P. (2010). Fundamentals of Human Resource Management (10th ed.). NY, USA: John Wiley and Sons, Inc.

Field, A. (2009). Discovering Statistics Using SPSS. Sage Publications.

Financial System, Banks, and FIs. (2021, July 10). Retrieved 7 3, 2021, from Bangladesh Bank: Central Bank of Bangladesh: https://www.bb.org.bd/fnansys/bankfi.php

Gruman, J. A., \& Saks, A. M. (2010). Performance management and employee engagement. Elsevier, 1-2.

Gruman, J. A., \& Saks, A. M. (2011). Performance management and employee engagement. Elsevier Inc., 123-136.

Gupta, V. K. (2013). Impact of Performance Appraisal Justice on Employee Engagement: A Study of Indian Professionals. Employee Relations, 35(1), 61-78.

Hair, J.F., Black, W.C., Babin, B.J., Anderson, R.E. \& Tatham, R.L. (2006). Multivariate data analysis. Pearson Prentice Hall Upper Saddle River, New Jersey, USA.

Hakro, A. N., \& Mathew, P. (2020). Coaching and Mentoring in Higher Education Institutions A Case Study in Oman. International Journal of Mentoring and Coaching in Education, 153.

HRM Practice. (2018). Retrieved from https://hrmpractice.com

Ibrahim, H., Rodzi, M. H., \& Zin, M. L. (2021). Factor Influencing Employee Engagement in a Financial Institution. Annals of Contemporary Development in Management \& HR, 3(1), 110. 
Ishtiaq, M., \& Zeb, M. (2020). Psychological Contract, Employee Engagement, and the Mediating Role of Job-Stress: Evidence from Pakistan. Business and Economic Review, 12(2), 83108.

Jena, L. K., Pradhan, S., \& Panigrahy, N. P. (2018). Pursuit of organizational trust: Role of employee engagement, psychological well-being, and transformational leadership. Asia Pacific Management Review, 23, 227-234.

Jones et al., J. R. (2016). The effectiveness of workplace coaching: A meta-analysis of learning and performance outcomes from coaching. Journal of Occupational and Organizational Psychology, 249-277.

Khan, W. (1990). Psychological conditions of personal engagement and disengagement at work. Academy of Management Journal, 33, 692-724.

Kahn, W. (1992). To be full there: Psychological presence at work. In W. Kahn, Human Relations (pp. 321-349).

Kariuki, N. W. (2015). Role of job design on employee engagement in private universities in Kenya: A case of the Presbyterian University of East Africa. The Strategic Journal of Business and Change Management, 365-385.

Keating, L. A., \& Heslin, P. A. (2015). The potential role of mindsets in unleashing employee engagement. Human Resource Management Review, 321-341.

Kaiser, H. F. (1974). An Index of Factorial Simplicity. Psychometrika, 39 (1), 31-36.

Kim, J.-O., \& Mueller, C. W. (1978). Introduction to Factor Analysis; What It Is and How to Do It. London, UK: Sage Publications.

Li et al., P. (2021). Country differences in the relationship between leadership and employee engagement: a meta-analysis. The Leadership Quarterly, 32(1), 1-14.

Locke, E. A., \& Latham, G. P. (2019). The Development of Goal Setting Theory: A Half-Century Retrospective. American Psychological Association, 5(2), 93-105.

Macey, W. H., Schneider, B. (2008). The Meaning of Employee Engagement, Industrial and Organizational Psychology, 1, 3-30.

Management. (2019, July). Retrieved from Encyclopedia: www.encyclopedia.com

Medlin, B., \& Green Jr, K. W. (2009). Enhancing performance through goal setting, engagement, and optimism. Emerald Group Publishing Limited, 943-956.

Mone, E. M., \& London, M. (2010). Employee Engagement Through Effective Performance Management - A practical guide for managers. New York: Routledge.

Mozammel, S., \& Haan, P. (2016). Transformational leadership and employee engagement in the banking sector in Bangladesh. The Journal of Developing Areas, 50, 43-55.

Mozammel, S., \& Haan, P. (2016). Transformational leadership and employee engagement banking sector in Bangladesh. The Journal of Developing Areas, 50(6), 43-55.

Nabi et al., M. N. (2017). Impact of Motivation on Employee Performance: A Case Study of Karmasangsthan Bank Limited, Bangladesh. Arabian Journal of Business and Management Review, 1-8.

Nair, M. S., \& Salleh, R. (2015). Linking Performance Appraisal, JUstice, Trust, \& Employee Engagement: A Conceptual Framework. Elsevier, 1155-1162.

Newaz et al., M. T. (2021). Managerial implications for construction practices as a consequence of using a psychological contract of safety. Engineering, Construction and Architectural Management, 28(4), 1134-1155.

O'Connor, E. P., \& Henry, M. C. (2019). Exploring the Relationship Between Exclusive Talent Management, Perceived Organizational Justice and Employee Engagement: Bridging the Literature. Journal of Business Ethics, 1-18.

Osborne, S., \& Hammoud, M. S. (2017). Effective Employee Engagement in the Workplace. International Journal of Applied Management and Technology, 16(1), 50-76.

Popli, S., \& Rizvi, I. A. (2016). Drivers of Employee Engagement: The Role of Leadership Style. Global Buinsess Review, 17(4), 965-979.

Radda, A. A., Majidadi, M. A., \& Akanno, S. N. (2015). Employee Engagement: The new model of leadership. Indian Journal of Management Science (IJMS), 17-26.

Rothbart, N. (2001). "Enriching or depleting? The dynamics of engagement in work and family roles". Administrative Science Quarterly, 655-684. 
Rousseau, D. M. (2001). promise and mutuality: The building blocks of the psychological contracts. Journal of Occupational and Organizational Psychology, 74: 511-541.

Saks, A. M., \& Gruman, J. A. (2014). What do we really know about employee engagement? Human Resource Development Quarterly, 155-182.

Saks, A. M. (2019). Antecedents and consequences of employee engagement revisited. Journal of Organizational Effectiveness: People and Performance, 1-21.

Sandhya, S., \& Sulphey, M. M. (2021). Influence of empowerment, psychological contract and employee engagement on voluntary turnover intentions. International Journal of Productivity and Performance Management, 70(2), 325-349.

Schaufeli, W. , \& Salanova, M. (2008). Enhancing Work Engagement through the Management of Human Resources. In K, Naswell, J. Hellgren, \& M. Sverke (Eds.), The Individual in the Changing Working Life, 380-402. New York: Cambridge University Press.

Schaufeli, W. B. (2017). Applying the Job Demands-Resources model: A 'how to guide to measuring and tackling work engagement and burnout. Organizational Dynamics, 121.

Sendawula et al., K. (2018). Training, employee engagement and employee performance: Evidence from Uganda's health sector. Cogent Business and Management, 5(1), 1-12.

Sexton et al., J. B. (2018). Providing feedback following Leadership Walkrounds is associated with better patients safety culture, higher employee engagement, and lower burnout. BMJ Quality and Safety, 261-270.

Shantz, A., Alfes, K., Truss, C., \& Soane, E. (2013). The role of employee engagement in the relationship between job design and task performance, citizenship, and deviant behaviours. The International Journal of Human Resource Management, 6.

Shoaib, F., \& Kohli, N. (2017). Employee engagement and goal-setting theory. Indian Journal of Health \& Wellbeing, 8(8), 877-880.

Shumi, R. A., \& Begum, S. (2017). Employee Engagement: A Tool for Enhancing Performance Management. European Journal of Business and Management, 9(19), 46-54.

Spiegelaere, S. D., Gyes, G. V., Witte, H. D., \& Hootegem, G. V. (2015). Job design, work engagement, and innovative work behaviour: A multi-level study on Karasek's learning hypothesis. Management Revue, 123-137.

Stangrecka, H. B., \& Iddagoda, Y. A. (2020). The relationship between inter-organizational trust and employee engagement and performance. Academy of Management, 1-18.

Stevens, J. (2012). Applied Multivariate Statistics for the Social Sciences. Routledge

Terpstra, D. E. (1994). The Relationship of Goal Setting to Organizational Profitability. Group \& Organization Management, P, 285-295.

The Balance Career. (2019, Jun). Retrieved from www.thebalancecareers.com

Williams, B. \&., \& Brown, T. (2010). Exploratory Factor Analysis: A Five-Step Guide for Novices. Australasian Journal of Paramedicine, 8(3), 1-13.

Zameer et al., H. (2018). Corporate Image and customer satisfaction by virtue of employee engagement. Human System Management, 233-248. 